Received: 6 June 2020 Accepted: 7 June 2020

Keywords: separation; bigamy; remarriage

\section{Escaping detection: illegal second marriages and the crime of bigamy}

\author{
Rebecca Probert
}

Abstract: Official statistics on the number of prosecutions for bigamy clearly cannot be taken as an accurate guide to the number who went through a ceremony of marriage with a second 'spouse' while still married to their first. Nonetheless, when we compare those who were prosecuted with those who were not, the differences that emerge should make us cautious in assuming that the offence was common. There is evidence to suggest that many of the unprosecuted may not have been bigamists at all, given how long they waited to remarry. Even those who did not wait may have believed or persuaded themselves that their first spouse was dead and that they were entitled to remarry. Others adopted tactics to ensure that their bigamous marriage would not be discovered, with most moving considerable distances before remarrying and a few adopting aliases to disguise their identity. The data from the sample suggests that it was the fact that most of these bigamies were undetected, rather than tolerance of bigamy within the community, that explains why they escaped prosecution.

\title{
Introduction
}

In evaluating our ancestors' marriages, it can be difficult to know what was common and what was exceptional. Official statistics are particularly unhelpful when it comes to the extent of marital breakdown in earlier centuries. The number of divorces gives no clue to the extent of informal separation. ${ }^{1}$ Nor do prosecutions for bigamy tell us anything about the number who went through a ceremony of marriage with a second 'spouse' while still married to their first. As Colwell notes in explaining the utility of the Criminal Registers as a source of information about bigamy, 'even if an ancestor's name is not found among these records it does not preclude his having been a bigamist, and it may just be that he was lucky enough to escape detection until the family historian set to work.'2

In this article I compare a sample of 369 individuals whose illegal second marriages went unprosecuted with 413 bigamists who were prosecuted for the crime of bigamy. My aim in so doing is to ascertain whether there were any differences between the two groups to indicate why some were never prosecuted, and whether inferences might accordingly be drawn about the nature, acceptability, and even the prevalence of bigamy in earlier centuries.

If, for example, a comparison showed that there were no material differences between the two in terms of when and where their illegal second marriages took place, then we might reasonably conclude that the likelihood of detection and prosecution was just as great for those who were not prosecuted. From this we might infer either that detection was a matter of pure chance or, alternatively, that the illegal second marriage was known at the time but nonetheless tolerated. And from this it would be reasonable to infer that those who were prosecuted were a small subset of a much larger group of bigamists, made to answer for their crime only where they were unlucky enough to have a vindictive first spouse or in-laws, or a second spouse seeking a justification to end the relationship. If, however, we were to find significant differences between the two groups - if, for example, the unprosecuted sample moved further or waited longer in order to remarry - then we might instead conclude that escaping detection was not merely a matter of luck but depended on the distance or time between the two marriages.

Indeed, the time that had elapsed before the illegal second marriage was essential to the matter of whether or not those who went unprosecuted were in fact liable to prosecution for bigamy at all. Here the legal definition of the crime needs to be borne in mind. In the absence of a divorce, any second marriage entered into during the lifetime of a validly married first spouse was null and void. But not all 
such marriages were bigamous. If the remarrying spouse had not seen their first spouse for seven years, and had no reason to believe that they were alive at any point during that time, ${ }^{3}$ then they had a good defence to any charge of bigamy brought against them, and were entitled to be acquitted if prosecuted. ${ }^{4}$ From 1889, a genuine belief that the first spouse had died was also a good defence to such a charge even before seven years had passed. ${ }^{5}$ In short, while all second marriages entered into during the lifetime of the first spouse were 'illegal' in the sense of having no legal status, only some were 'illegal' in the sense of exposing the remarrying spouse to a criminal prosecution for bigamy.

In that sense, then, if a significant proportion of the unprosecuted waited at least seven years before remarrying then we might want to err on the side of caution in our estimates of bigamy as a crime. And if escaping prosecution was not merely a matter of chance but depended on an individual putting considerable time and distance between their first and second marriages, we need to ask how many others would have been able to do the same.

Before exploring these issues, a brief explanation of the two samples is necessary.

\section{Collecting the data}

The focus of the project was on bigamists who had had at least one marriage (whether the first or subsequent) in England and Wales. Given the obvious challenges in assembling a cohort of bigamists who were never prosecuted from any official sources, a request for information was circulated to family historians via the Lost Cousins genealogy network. Respondents were invited either to complete a short online survey, or to respond by email, with details about any bigamous ancestors who had married in England and Wales. ${ }^{6}$ The sample of 369 was made up of 276 examples provided by 176 family historians who responded by email and a further 93 examples provided by the online survey. ${ }^{7}$

The sample covered a broad time period, from the early eighteenth century to the mid-twentieth. The first of the first marriages took place in 1708 , and the last of the second marriages in 1966. However, the cases were not spread evenly over the period. Only four examples occurred in the eighteenth century, and cases remained relatively rare during the first half of the nineteenth. Almost half of the second marriages took place between 1850 and 1900 .

The primary comparator group consisted of 413 bigamists who were prosecuted at the Assizes in the 1850s. Data on this sample was compiled from a combination of the Criminal Registers, which recorded basic details of those prosecuted, and newspaper reports giving further details of where and when the marriages took place. Given that the bulk of the unprosecuted sample went through a second marriage in the nineteenth century, a mid-century sample seemed the most apt comparator, but comparisons are drawn with broader trends where the data permits.

\section{The distribution of cases, behaviour, and gender}

The fact that the unprosecuted sample was drawn primarily from the nineteenth century was perhaps to be expected, given the greater difficulties in researching eighteenth-century families and the sensitivities of revealing more recent bigamies. It cannot necessarily be taken as indicative of changes in the number of unprosecuted bigamies over time. Nonetheless, it is worth noting that the distribution of unprosecuted cases across the nineteenth century is not dissimilar to that of prosecuted cases, with relatively few occurring in the first three decades, an increase in the 1840 s and 1850 s, and the bulk of the cases occurring in the second half of the century. ${ }^{8}$

That is particularly significant when viewed against the data on sentencing patterns in the first half of the nineteenth century. Those convicted of bigamy in the first two decades ran a high risk of being transported to Australia. As the likelihood of transportation gradually receded and was reserved only for the most serious cases, the number of prosecutions increased. ${ }^{9}$ By itself, this might suggest a greater willingness to prosecute less serious cases when the consequences of a conviction were less devastating. But viewed in conjunction with the trends in the unprosecuted sample, the more likely explanation is that individuals were less likely to commit bigamy when this meant running the risk of transportation, and that the small number of prosecuted cases does in fact reflect a low number of individuals committing bigamy.

However, it does not seem that those who were prosecuted for bigamy had behaved any worse than those who were not. While the case law reveals the greed, deceit, and nastiness of a number of bigamists, cases of financial exploitation, the abandonment of successive spouses, and multiple marriages were still a minority. ${ }^{10}$ Most bigamies that came to court seem to have been a response to marital breakdown rather than part of a criminal career. At the same time, some of those who were not prosecuted had deserted both their first and second spouses, and had occasionally entered into yet another illegal marriage. In other words, we cannot explain away the prosecution of some bigamists and the lack of prosecution of others by how 'aggravated' their behaviour was. 
When we turn to the gender of those who went through an illegal second marriage, a difference between the prosecuted and the unprosecuted suddenly presents itself. It was striking that, although unprosecuted female bigamists were in the minority (40\%), ${ }^{11}$ this was a much more substantial minority than within the prosecuted sample. During the eighteenth century, women had accounted for around onethird of those prosecuted for bigamy at the Old Bailey. ${ }^{12}$ In the nineteenth century, the proportion of women prosecuted for the crime dropped considerably: between 1805 and 1853 they accounted for just $18 \%$, and between 1857 and 1950 the average was just under $22 \% .{ }^{13}$

The relatively high proportion of female bigamists in the unprosecuted sample indicates that the official statistics are not necessarily a reliable guide to who actually entered into an illegal second marriage. As the next section will show, however, it would be wrong to jump to the conclusion that a significant number of individuals were committing bigamy without being prosecuted.

\section{Could a prosecution have been brought?}

In assessing whether those in the unprosecuted sample could have been prosecuted, the first question is whether the offence had been committed at all.

In order to commit bigamy, an individual had to have been validly married in the first place. So one defence was that the first marriage had been void for some reason. In one of the unprosecuted cases, what looked like a bigamous marriage turned out to be entirely legal, if only on the highly technical basis that the supposed bigamist's first wife had herself been married to someone else at the time of their marriage.

The more common defence was that the other spouse had been absent for seven years and the remarrying spouse had no reason to believe that they were alive during that time. This, it should be noted, was not quite the same as a belief that the other spouse was dead: the burden of proof was on the prosecution to show that the remarrying spouse was aware that their first spouse was still alive. ${ }^{14}$ This distinction is important in assessing the likelihood of those in the unprosecuted sample being able to establish this defence.

The evidence suggests that a significant percentage within the unprosecuted sample may well have had such a defence. Within the unprosecuted sample, the average (mean) time elapsed between the first and second marriages was 16 years. ${ }^{15}$ Within the prosecuted sample, it was under ten years. ${ }^{16}$ In other words, the average difference between the prosecuted and the unprosecuted is almost exactly seven years.

Of course, as a test of whether or not the second marriage was also in fact bigamous, in the sense of being a crime, measuring the lapse of time between first and second is a somewhat crude measure. It does not tell us how much time elapsed between the separation from the first spouse and the marriage to the second, still less whether the remarrying spouse had heard from the other during that time. There is however supporting evidence in many cases that the couple had separated at least seven years before the illegal second marriage. One man had joined the army three-and-a-half years after his first marriage; his second marriage, to the widow of a former comrade, took place some 18 years later. In a second case a woman remarried 23 years after her husband had gone to America with her sister.

Inferences can also be drawn from when children were born and from when couples last appeared together in the census. Of the 132 cases where the time lapse between first and second marriage was 14 years or more (allowing seven years for the breakdown of the first marriage and seven years' separation before the second), in only 11 cases was there evidence that the separation had occurred less than seven years before the second marriage. Before 1889, let us recall, any such remarriage would automatically be bigamous; after that point, only if the remarrying spouse could genuinely be said to have believed that their first spouse was dead might they escape a charge of bigamy. Nine of these cases involved a husband committing bigamy after a long-lasting first marriage, and it seems unlikely that any defence would have been available to them. The remaining two were women: one whose first husband was in prison at the time, and one who remarried shortly after her first husband had been acquitted of bigamy on the basis of the seven-year defence: the irony was that this made her guilty of bigamy, as her knowledge that he was alive at the time of the trial would have meant that she could not rely upon the seven-year defence until another seven years had passed in which she had not heard of him.

When we turn to those cases where the time elapsed between first and second marriage was between seven and 14 years, there were a number of cases where the evidence showed that the couple had in fact been separated for seven years by the time of the second marriage. One couple, married in August 1839, had separated by the time of the 1841 census; the husband's remarriage in June 1848 suggests that he was paying close attention to the seven-year defence. In another case, in which the time elapsed between the first and second marriages was a little over ten years, there was evidence to suggest that the first marriage had broken down within a couple of years. And in a third at least eight years had elapsed between the breakdown of the first marriage (as evidenced by the wife's bigamous remarriage) and the husband's illegal (but possibly not criminal) remarriage. 
This evidence of individuals strategically observing the seven-year rule suggests that family historians might be able to draw inferences about when the separation occurred when faced with a gap in the evidence. To take one case from the sample, a woman who had married in 1871 was living with her parents at the time of the 1881 census, having reassumed her maiden name. Her second marriage took place late in 1886 , suggesting that the separation from her first husband most likely took place in the late 1870s.

Of course, the one unknown factor in many of these cases is whether the remarrying spouse knew that their first spouse was still alive. In some cases we can be fairly confident that they did not, for example where the two were on opposite sides of the globe. One couple who married in Bristol in the 1860s both remarried around 30 years later - the wife on the Isle of Wight and the husband in Tasmania (having travelled via South Africa and New Zealand). In other cases it seems highly unlikely that the remarrying spouse did not know. One man's second marriage took place just eight miles away from the village where his first had been celebrated and where his first wife was still living. And in others we simply cannot tell. However, as long as the remarrying spouse had not heard from or of the other spouse during the seven years prior to their second marriage, they would have been able to satisfy this defence.

The fact that so many individuals waited to remarry - even if this meant deferring the formalization of a new relationship - tells us something important about attitudes to marriage, marital breakdown, and bigamy. The historian Ginger Frost has rightly pointed out that committing bigamy - rather than cohabiting with a new partner - can be seen as a form of respect for the institution of marriage. ${ }^{17}$ Waiting until it was possible to remarry without committing bigamy can be seen as demonstrating respect for the law, or at least a desire to avoid the risk of prosecution.

There were, in addition, two post-1889 cases where the second marriage took place within seven years of the first but there was evidence to suggest that the remarrying spouse may genuinely have believed that their first spouse was dead and so would have been entitled to be acquitted if the matter came to court. Both involved women whose husbands had left the family home, and of whom nothing more is known. These may well have been legitimate remarriages, despite the slight deceit in both describing themselves as spinsters, and unless the first husband had turned up there would have been no reason to prosecute them.

Once we add together all cases in which it is plausible that the remarrying spouse would have had a good defence to bigamy on the basis of their first spouse being already married, the seven-year defence or, after 1889, a genuine belief in the death of the first spouse, they account for $65 \%$ of the sample.

Of course, this does not guarantee that $65 \%$ were not guilty of bigamy, given the uncertainty as to whether the remarrying spouse knew the other to be alive. At the same time, we should bear in mind that the burden of proof would have been on the prosecution to show that the remarrying spouse was aware that their first spouse was still alive, ${ }^{18}$ and take the same approach in interpreting the evidence. Moreover, in interpreting our ancestors' behaviour - and explaining why these individuals were not prosecuted - beliefs about the law may have been just as powerful as what the law actually said. We know from cases that reached the courts that it was the fact of seven years' separation, rather than whether or not the other spouse was known to be alive, that most people focused on. ${ }^{19}$ So even if we cannot be confident that all of the $65 \%$ were not technically guilty of bigamy, it would be reasonable to assume that most of them believed that they would not be risking prosecution for bigamy in remarrying.

\section{Why might the bigamy have escaped prosecution?}

We can now focus on the smaller group of those who do not appear to have any defence to bigamy but still escaped prosecution. In this section the distance between the first and second marriages will be considered, together with what is known of the other spouse, and the use of aliases.

\section{Distance}

The most striking difference between unprosecuted and prosecuted bigamists lies in the distances they travelled between their first marriages and illegal remarriages. Among the prosecuted sample, the mean distance between first and second marriages was 97 miles, and the median just $18 .{ }^{20}$ Only two had put over 1,000 miles between their first and second marriages, and none had travelled more than 5,000 miles. Among the unprosecuted, by contrast, the mean distance was 1,746 miles and the median 60 miles, with a quarter of the sample travelling over 1,000 miles and around $10 \%$ travelling over 10,000 miles. $^{21}$

Travelling over 1,000 miles obviously entailed going outside the UK - even Lands End to John O'Groats is only around 800 miles. And bar one whose first marriage had taken place in Malta, those unprosecuted bigamists who had put over 1,000 miles between their first and second marriages had all married outside Europe. Australia and the United States and were the most popular countries, accounting for nine and seven 
marriages, but there were also marriages in South Africa, New Zealand, Canada, Mesopotamia, Argentina and China. One went on to put a similar distance between their illegal second marriage and their third: this individual, who had married first in Buenos Aires and the second time in London, then went through a third marriage in New York.

There was, however, a clear gender divide in the distances travelled. Over half of the men who had not waited to remarry had moved over 100 miles, as compared to under $10 \%$ of the women. Men, of course, had greater opportunities to travel. There are some clear examples in this study of men whose ability to move long distances was facilitated by their job. Lincolnshire-born William Charles Exton was a soldier in the county regiment when he was posted to Malta in 1895. As family historian Alan Bloor discovered, Exton married Antonia Sciberras there a year later, having been transferred to the Army Reserve, but was then 'recalled to the Army in December 1899 and sent to South Africa, finally being discharged in January 1902. ${ }^{22}$ Upon his return to England, he married for a second time, despite his Maltese wife still being alive. The sample also included another three soldiers, a master mariner, a naval officer, and a couple of ordinary sailors, along with a ship's cook, a steward, and a stoker. Within this hyper-mobile group of men for whom travelling long distances was a matter of course, it is unsurprising that illegal second marriages went undetected.

Yet it hardly needs to be pointed out that not all men had the opportunity to travel or the reassurance that they would find work if they did. Migrating individuals often made use of existing connections to support them in their new environment. But joining those who originated from the same small community would have made it impossible to start a new life with a new spouse without being detected.

And when we compare the occupations of those who were prosecuted with those who were not, one difference is immediately obvious. Labourers formed the largest single group among the prosecuted sample, but barely featured at all among the unprosecuted. By contrast, white-collar and professional occupations were more heavily represented among the unprosecuted sample than among the prosecuted. While the numbers are too small to analyse whether the distance between first and second marriage differed by occupation, it is worth noting that the farm labourer who travelled over 10,000 miles between his first and second marriages did not do so of his own accord: transported to Australia for a different offence, he remarried there. Putting aside such involuntary moves, however, the data suggests that class, as well as gender, played a role in determining who was able to put some distance between their first and second marriages and thereby escape prosecution.

Distance is, of course, a somewhat crude proxy for measuring detectability. Some bigamists were detected and prosecuted despite travelling thousands of miles; others escaped prosecution despite marrying in the same place. But it is nonetheless significant that over half (53\%) of those who had not waited to remarry had put 50 miles or more between their first and second marriages.

\section{Absent spouses}

The distance between the first and second marriage may not always tell the full story as to the distance between the spouses at the time of the second marriage. Here the richness of the data provided by family historians was particularly useful in revealing how the movement of individuals around the globe may have enabled bigamists to escape detection. In two particularly striking cases, both the first and second marriages took place just a few miles apart in London, but by the time of the second marriages the first spouses were far away-in New York and Sydney respectively.

There is evidence to suggest that the first spouse was at some distance in eight (18\%) of the 44 cases where the second marriage took place within a relatively short time and distance of the first marriage. In one case the first husband was a seaman and known to have been at sea the year before his wife's bigamous remarriage. In such cases the remarrying spouse may well have assumed (or claimed) that the absent spouse was dead, with this assumption being shared by the community. Before 1889 such remarriages would technically have been bigamous even if the remarrying spouse had genuinely believed the absent spouse to be dead, but prosecutions of such cases were only instituted if the first spouse could be proved to be alive.

\section{Aliases and anonymity}

Of the remaining 36 cases, seven of the remarrying spouses had used an alias or some variation of their name to disguise their identity. At least five of the remarriages had taken place in a register office after the change in 1856 that required notices of marriage to be displayed in the superintendent registrar's office with no other attempt at publicity. And in nine cases the parties were living in London, where anonymity could more easily be secured without travelling too far. By contrast, two bigamists had emigrated to different continents shortly after their weddings, while another (a sailor) also travelled to the other side of the world, as evidenced by his third marriage in New Zealand. Overall, then, it seems that only a handful of those who were unprosecuted were simply lucky to get away with it. 


\section{Double remarriages}

One final characteristic of the unprosecuted sample should be noted. As noted above, many family historians provided details of more than one illegal second marriage. The most common reason for this was where a single separation had resulted in both of the spouses remarrying. This was the case for 74 individuals, or just over one-quarter of the email sample. The fact that both went unprosecuted raised the question of whether there was greater tolerance of bigamy by the community in such cases, or whether bigamy was more likely to be prosecuted if there was an unremarried first spouse nursing an unresolved grievance. However, upon examining where and when both spouses remarried, these double remarriages tended to reflect one or both of the elements already discussed. Either both spouses waited for the years to pass, or one moved and the other waited, or both moved.

There were two cases in the sample where an illegal second marriage was celebrated in the very same church as the first marriage. In one, the remarriage took place at least 16 years after the departure of the first wife (who herself had remarried over 80 miles away in Suffolk), and the likelihood is that the community assumed that he was the widower that he claimed to be. In the second case, the first marriage had similarly been over for at least 16 years - the husband having been living with another woman during that time - and the wife had remarried elsewhere.

As this suggests, double remarriages were not necessarily linked. In some cases, the two remarriages were so close in time as to suggest some communication between the original spouses. One couple had married in Devizes in 1854 and had separated by 1861; each remarried new spouses in 1875, less than three months apart (but at some considerable distance from their first marriage and each other). In another case, both husband and wife remarried bigamously during the same quarter, again after well over seven years had elapsed since their separation and many miles apart. But these cases were very much the exception. Usually the time elapsed between the respective remarriages was much more significant. The mean lapse of time between the remarriage of one spouse and that of the other was just under eight years, and the median just under six. And in one case 33.5 years elapsed between the two events.

In only one case can the lack of a prosecution be explained by the fact that the other spouse had remarried rather than by some combination of time and distance. In this case, the husband and the wife both went through bigamous remarriages in the same church: significantly, however, this was not the church where they had originally married. The marriage of this particular couple had broken down after they had left their home parish, and they were able to pass as bachelor and spinster when they remarried within a year or so of each other in another town. It does not, therefore, offer any real support for the idea that double remarriages went unprosecuted because they were tolerated.

\section{Conclusion}

Faced with a large sample of richly detailed stories of bigamy, it would have been easy to conclude that bigamy was a common occurrence in nineteenth and early twentieth-century England and Wales. But it should be noted that, while a few family historians had multiple cases to report, this was usually in the context of an exceptionally large database. The founder of the Howes One-Name Study, for example, provided details of seven cases, four of which involved prosecutions, and three which did not. This, however, was in the context of a database of 150,000 people in reconstructed families. Similarly, Alan Craxford supplied 12 examples from a database containing around 20,000 names and 6,052 married persons.

Indeed, many of the bigamous marriages that had been discovered by family historians had only come to light fairly recently. Some had been intrigued by stories of mysterious ancestors who had disappeared or always been discussed in hushed tones and had been prompted to investigate them further. But many emphasised that it was only through modern technology, whether the linkage of data on genealogy websites or DNA tests, that they had managed to uncover an ancestor's bigamy. Sometimes a relationship was unearthed when individuals realised that they were researching the same family as others of whose existence they had been unaware. On other occasions a side-line of enquiry suddenly opened up hitherto unsuspected relationships.

But it seems to have been the strategies adopted by these individuals, rather than pure luck, that meant they had not been prosecuted. In the vast majority of cases there was a good reason why those in the unprosecuted sample had not been prosecuted. As many as $65 \%$ may not have been bigamists at all, given how long they waited to remarry. Others adopted tactics to ensure that their bigamous marriage would not be discovered, by travelling some distance, waiting until their spouse had been absent for some time, or adopting an alias. But given that moving to start a new life was likely to require some resources, it was not an option available to all, as the far greater proportion of unskilled labourers among the prosecuted sample demonstrates. The differences between those who were prosecuted for bigamy and those who were not cast serious doubt on the idea that there were many known bigamists whose actions were tolerated by the community. Only a tiny number were just lucky to get away with it. 


\section{References}

1. Gibson, Colin. (1994) Dissolving Wedlock (London: Routledge).

2. Colwell, S. (1980). The Incidence of Bigamy in 18th and 19th Century England. Family History. p. 91

3. The precise nature of the defence shifted over the period: before 1828, the fact that one's spouse was overseas for seven years was a defence even if they were known to be alive.

4. 2 Jac. II, c. XI, s. 2; 9 Geo. IV, c. 31, s. $22 ; 24$ \& 25 Vict., c. 100 , s. 57 , http://www legislation.gov.uk/ukpga/Vict/24-25/100/crossheading/bigamy

5. $R \vee$ Tolson (1889) 23 Q.B.D. 168

6. https://www.lostcousins.com/newsletters2/latefeb19news.htm\#Bigamist.

7. I would like to express my gratitude to all those who responded, particularly those who completed the online survey, whom I have not had the opportunity to thank personally. Among those who provided information and were happy for their involvement to be acknowledged were Cindy Alder, Rian Anderson, David Andrews, Rosie Ansell, Jenny Armour, Val Bachelor, Elaine Banks, Sandra Bates, Richard Bawden, Paul Billington, Brian Binns, Marina Black, Alan Bloor, Wilson Bolsover, Ann Bond, Elaine Bonneau, David Bovington, Jill Bradbury, Elizabeth Briggs, Colin Broughton, Shirley Brown, Simon Bull, Steve Bumstead, Adam Bunting, Mike Burnham, Irene Caldwell, Sally Canham, Gill Chesney-Green, Christopher Clegg, lan Cole, Chris Coleman, Elizabeth Conway, Dorothy Cooper, Jan Costin, Lorna P. Cowan, Alan Craxford, Carlè Crozier, lan Day, Shelagh Delphyne, Linda Dennis, John Durham, Denis Edwards, Christine Ensor, lan Evans, Wayne Farmer, Barbara Fisher, Gordon Foulkes-Jones, Lucinda Ganderton, Jo-Anne Gannon, Shelagh Garside, Lorna Gibson, Carole Giffen, Heather Goff, Carolyn Greenwood, Rebecca Gurney, Kevin Haley, Linda Hall, Kay Halley, Barbara Handley, Heather Hayes, Sue Heys, Norman Holloway, Eric Hopley, Susan Hora, Paul Howes, Sarah Hughes, Yvonne Hughes, Peter Humphrey, Clare Humphreys, Linda Hutton, Janet James, Pat Jones, Richard Jones, Gillian Kendrigan, Geoff King, Frances Lake, Stephen Larkin, David Leach, Bridget Lewis, Ailsa Logan, Maggie Luscombe, Donna Maycock, Rob McBride, Jane Milbourne, Normandie Miller, Eileen Milton, Neil Mitchell, Liz Mitchell, Yvonne Mitchell, Pat Mundell, Rose Murrell, Shirley Oakland, Sid Norman, Josie Norris, Katerina Papatheodoropoulos, Liz Parmenter, Brenda Paternoster, Alexander Paterson, Jennie Parfitt, Sandra Parker, Jenny Pedley, Alex Pinhorn, Ann Piper, Bill Piper, Hannah Plowman, Jan Polkinghorne, Tim Powys-Lybbe, Mary Hartley Price, Leigh Prideaux, Rosemary Probert, John Pruce, Maureen Rawson, Pat Ribbans, Ann-Maree Richardson, Barbara Roberts, Jean Ross, Katy Russell-Duff, Peter Scott, Susan Sherman, Barbara Smith, Maggie Smith, Dianne Shenton, Sue Shore, Jean Spelman, Neil Spurgeon, Gill Taylor, Karen Taylor, Rose Taylor, Marie Teasdale, Elaine Thomas, Jeannette Thornell, Brian Thompson, Jim Tidmarsh, Mervyn Tims, Joyce Trousdale, Jennifer Tucker, Jerry Turner, Ali Walker, Rob Walsh, Colin Ward, Amanda West, David Wharton, Bill Whykes, Jane Williams, Liz Williams, Helen Wright, and John Young.
8. Probert, Rebecca, and D'Arcy-Brown, Liam. (2019) The transportation of bigamists in early nineteenth century England and Wales. Journal of Legal History, 40 (3). p. 223; Cox, David, (2012) "Trying to get a good one": Bigamy Offences in England and Wales, 1850-1950. Plymouth Law and Criminal Justice Review, 4. p. 1.

9. Probert, Rebecca, and D'Arcy-Brown, Liam. (2019) The transportation of bigamists in early nineteenth century England and Wales. Journal of Legal History, 40 (3). p. 223.

10. Probert, Rebecca, and D'Arcy-Brown, Liam. (2019) The transportation of bigamists in early nineteenth century England and Wales. Journal of Legal History, 40 (3). p. 223.

11. Based on a sample of 275. In terms of who committed bigamy, the online survey deliberately did not ask for the gender of the bigamist, to limit the possibility of 'jigsaw' identification through piecing together different bits of information. By contrast, all but one of those who emailed provided information about gender.

12. Probert, Rebecca. (2013) Double Trouble: The Rise and Fall of the Crime of Bigamy. Selden Society.

13. Probert, Rebecca, and D'Arcy-Brown, Liam. (2019) The transportation of bigamists in early nineteenth century England and Wales. Journal of Legal History, 40 (3). p. 223; Cox, David, (2012) "Trying to get a good one": Bigamy Offences in England and Wales, 1850-1950. Plymouth Law and Criminal Justice Review, 4. p. 1.

14. $R \vee$ Mary Briggs (1856) D. \& B. 98; 169 E.R. 933; $R \vee$ John Curgerwen (1865-72) L.R. 1 C.C.R. 1.

15. Based on 264 cases. The data from the online sample was excluded from this part of the analysis as the survey had not asked for information about separation, making assessments of whether the seven-year defence was satisfied impossible. A further 11 cases were excluded from the email sample: five because the fate of the first spouse was unknown and these may have been legitimate remarriages, five because only limited data was provided, and one because the bigamist was in fact charged.

16. Based on 134 cases for which this information was available.

17. Frost, Ginger. (1997). Bigamy and Cohabitation in Victorian England. Journal of Family History, 22. p. 286.

18. $R \vee$ Mary Briggs (1856) D. \& B. 98; 169 E.R. 933; $R \vee$ John Curgerwen (1865-72) L.R. 1 C.C.R. 1.

19. See e.g. Liverpool Mercury etc, August 18, 1843; Daily News, August 18, 1854; The Royal Cornwall Gazette, Falmouth Packet, and General Advertiser, August 4, 1854; Daily News, August 18, 1854; The Bristol Mercury, July 26, 1856; The Standard, May $14,1857$.

20. Based on 137 cases for which information was available

21. Based on 93 cases for which information was available.

22. Derbyshire Family History Society Magazine (2010).

\section{ABOUT THE AUTHOR}

Rebecca Probert is Professor of Law at the University of Exeter. Her research focuses on the law and history of marriage, bigamy, divorce and cohabitation and she is the author of numerous articles and books, including Marriage Law and Practice in the Long Eighteenth Century: $A$ Reassessment (2009), The Legal Regulation of Cohabitation: From Fornicators to Family, 1600-2010 (2012) and Tying the Knot: The Formation of Marriage 1836-2020 (2021), all published by Cambridge University Press. She has also published a number of guides for family historians, including Marriage Law for Genealogists (2012) and Divorced, Bigamist, Bereaved? (2015). She has appeared numerous times on TV and radio, including Harlots, Heroines and Housewives, A House Through Time and Who Do You Think You Are? 